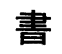

神野慧一郎『モラル・サイエンスの形成——ヒュー 厶哲学の基本構造一』(名古屋大学出版会, 1996 年 6 月 10 日刊, A5 判, xiii $+312+10$ ページ)

\section{藤本 隆志}

長年ヒューム研究に携わってこられた本学会会員神 野慧一郎氏が「ヒューム研究』(ミネルヴァ書房, 1884 年) 以降 10 年余を経て上梓された，氏のヒューム研究 総決算とも称すべき労作である。論述は平明であるが, その切りこみは深く, 評者は教えられるところ多大で あった。

ヒュームといえば，ひとは従来『人間本性論』第 1 巻 「知性論」の一部分だけに着目して, その因果性批判と ともに形而上学に対する懐疑を強調し, これによって カントが独断の夢を醒まされたといつた哲学史教科書 風の理解で話を済ませがちであった。これに対して, 神 野氏は「知性論」の検討には 30 ページたらずの紙面を 費やしただけで, 以後は第 2 巻「情念論」と第 3 巻「道 徳論」の検討, そして後半では政治哲学や 18 世紀当時 の政治イデオロギー, さらにはヒュームの説明概念の 分析を行いつつ, 彼の意図が人間モーレスの研究とし ての「モラル・サイエンス」にあった事実を高々と指 摘する。また，類書にありがちな「人」と「思想」の 分断叙述は行わず（序章と中間の補章でスコットラン ド対イングランドの時代思想風土の解説が挿入される が), ヒューム理解に必要なかぎりで適宜両者の渾然一 体化した論述を行っているのも, 本書を読みやすくし ている特色の一つである。

以下著者の指摘する多くの論点のうち, 評者の印象 に残った論点若干を枚挙してみる。

（1）デカルトの場合も，ヒュームの場合も，一見 ファジーに見える「情念」に関する諸問題を神野氏が 重点的・主題的に取り上げたことは, 注目に值する。引 用されているアーダルらの情念分類 (一次-二次, 強弱, 直接-間接)なども大変参考になった。古代ギリシ ア以来の理性・気概・情欲といった霊魂機能区分の下 で最下位に位置づけられてきた情的・様態的なものや ポイエーシスの領域に, 現代の哲学的関心が集約され つつあるように思われるからである。

\section{評}

（2）ヒュームにあっては理性主義的倫理説が退け られ，道徳的承認・不承認のごとき道徳的区別を決め るのさえ情念とされるから，行為が理性（観念や想像 や推論）を動機として発動することはなく，もっぱら 愛憎や気質や習慣のような情念（印象）を原因として 生ずるという論点は, たとえば意図や信念を行為の原 因と見なすデイヴィドソン流行為因果説との対比で再 吟味さるべき論点であろうかと思われる。現在行われ つつあると思われる哲学の「行為論的転回（ないし展 開)」に対しても,ヒュームは重要な問題点を提起する。

（3）正義が人為的（非自然的・社会的）なものであ り,かつ, 個々の行為に関わるのでなく, 行為を行う 者の徳性（アレテー状態）に関わるというアリストテ レス的正義観をヒュームが共有していた事実,そして，

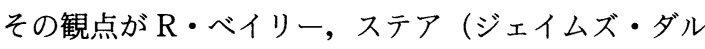
リンプル), ハッチソンを経てヒュームに伝えられた歴 史的経緯が巧みに要約されていて，現在の我が国にお けるスコットランド理解の不備を大いに自戒させられ た。さらに言えば，哲学史の常識に反して，ヒューム がイングランドのロックやアイルランドのバークリな どよりも，むしろキケロ，ホッブス，ハッチソンなど から直接影響を受けたことを本書に従って銘記すべき であろう。

（4）正義といった観念ないし理念を説明するため に採ったヒュームの方法が歷史的発展の提示という自 然誌的方法であったという指摘は，のちの後期ウィト ゲンシュタインなどの方法を想起させて, まことに興 味深い。それはなるほど保守的なやり方ではあろうが, 何が行われているかを冷静に展望するための唯一の方 法であろうかと思われる。

（5）超歴史的かつ普遍的な理念や理論やイデオロ ギーのごときものを想定し，これを金科玉条にして現 実批判を行うのではなく，歴史的現実のなかで与えら れた人間の経験世界を見通すことがヒューム経験主義 の視点であったのだとすれば，現代のわれわれもこの 視点からわれわれ自身とわれわれを取り巻く世界の現 実をさらに怜悧に見通してみなくてはならない。本書 が指摘するように, これがヒュームからわれわれの学 ぶべき最重要の課題であろう。 
（6）総じては, 神の誠実さや生得観念やアプリオリ な諸原理やに基づく合理論的立論を拒んだヒュームの 冷静で自然主義的な経験論がこの書物では極めて説得 力あるしかたで概観され，ヒューム再検討の必要が自 ずから示唆される。本年度ある学会が大会ワーク ショップのテーマにデカルト（今年は年誕 400 年）と ヒュームの再検討を選んだのも故なきことではあるま w。

Paul Feyerabend: Killing Time, The Autobiography of P.F., The University of Chicago Press, 1995

\section{村上陽一郎}

ファイヤアーベントが 1994 年になくなり,クーンが 今年逝った。新科学哲学派と言われた 1920 年代生まれ の問題児たちが，一人一人久けていく。科学哲学の領 域を越えて, 彼らの仕事は知的社会にさまざまな衝撃 を与えたが，それももう過去のエピソードの一つに数 えられることになってしまった感もある。一度, きち んと彼らの学問的決算をしなければならないと思う が,ここでは, その层はない。しかし, ファイヤアー ベントの死に際して, Zeit 紙などヨーロッパの主要な 新聞や雑誌が組んだ特集記事の大きさに，あらためて 彼の存在の意味を思い知らされた。

ファイヤアーベントが UCバークレイ校とツューリ 七工科大学を引退してのち, 自伝めいた著作に手を染 めていることは，以前に『知を巡る三つの対話』を翻 訳したときに知ったが，それが全くの絶筆になるとは 思ってもみなかった。本書は, その絶筆となった自伝 である。

彼のような反逆児が自伝を書くとは，という意外感 があることは予想できる。実際『知を巡る三つの対話』 でも，「一体 [自伝を書くとは］何様のつもりだ」と自 分でも書いていたくらいである。しかし，そこでも記 していたことは,そして本書でも最初に述べているが, 自分の歴史を書くことに拘泥せざるを得なくなった きっかけがあったという点である。1938 年, 彼の祖国 オーストリアは, ナチス・ドイツに併合された。そし てそれから 50 年後の節目の年, 1988 年には,さまざま な行事がオーストリア国内では催された。それらは, ど こかで空虚で, 嘘臭く感じられた, とファイヤアーべ ントは言う。それは, 一方では, 50 年前, オーストリ アの人々の大半が, ナチス・ドイツの傘下に入ること を喜び, 歓迎し, 進んで受け入れたという記憶による
ものであり，他方は，それゆえにまた，真摰な反省に しても，自己批判にしても，謝罪にしても，公式の言 明や声明が持つどこか偽善的で，どこか欺瞞的な性格 から脱け出せていなかったからだ，と彼は考える。そ して振り返って自分はどうだったか。

少年時代にナチス化するオーストリアに生きて, 何 を感じ，何を感じていなかったか，ドイツ軍の一員と して徵用され, 戦場に出, 三発の銃弾を身に浴び, 障 害を負い，鉄十字章まで貪った過去は何だったか。そ れを，何の飾りも自己弁護もなく，率直に語ってみた ら, 少しは時代のオーストリア社会の真実が伝わるの ではないか。

それが動機だった,とファイヤアーベントは言う。そ して, 彼は, その点以外でも, 極めて率直に, したがつ て, 彼のトレードマークである偽悪の趣味も抑制され て, 自分の生を再現しようとする。書物への傾到, 学 問のキャリア，もろもろの大学との関わり，音楽と芝 居との離れ難い結び付き，女性との情事と繰り返され る結婚の失敗, そして, 最後に出会ったグラツィアと の愛。

類い稀な率直な語りのなかから, 類い稀な一つの知 的な魂の記録が生まれる。このジャンルの書物として は破格だろう。定量的に調べたわけではないが，学問 の話は全体の分量のほほ半分。それでいて, 彼の生涯 とほとんど重なった，今世紀ヨーロッパとアメリカの 科学哲学の歴史が, 鮮やかに浮き彫りになる。問題の ポパーとの関係も, 何の街いもなく, 思ったまま, 感 じたまま。率直は時に厮味なものだが，とりわけそそ れが装われるときには, 付き合いづらいものだが, こ こでは，その負の面は全く感じられない。

同時に職業的歌手を目指した, そして半ばそのキャ リアを手に入れたほどの, 音楽への才能, あるいはブ レヒトに認められるまでになった芝居の才。こうした 面に関する記述の織りなすタペストリは，面白いの一 語で通ずる。

巻末に縓められた幼時からの写真の数々も, 一人の 魂の記録として印象深いが，ここでは，彼は，例のヤ ンチャな露悪家ぶりを存分に発揮している。アメリカ の哲学者, あるいは学者の多くが, 何かの受賞式の写 真や，プロの指導でポーズして写した写真などをアル バムから選ぶのに反して, 台所で割京着を着て皿洗い する姿やら，指を口と鼻に突っ込んで「イー」をした （子供じゃあるまいし!)ものなどを選んだ彼の機知を， 読者は堪能するに違いない。 
病魔の進行は早く, モルフィネの大量投与のなかで 意識を失い, 本書の最後の部分は, グラツィアの手を 煩わせなければならなくなった。

学問とは何か, 最も勝義の意味での「アミチュア」意 識から, その精髄へと迫りながら, 見事なオブスキュ ランティズム（と言えば悪いものと相場が決まってい
るが）のなかに，人間にとって真理を追求することの 意味を，身近に感じさせてくれた本書には，必ず多く の読者が得られると思っている。

一言付け加えれば，評子の訳で邦訳は産業図書から 出版の予定である。 